\title{
COMPLIANCE WITH IAS 24 RELATED PARTY DISCLOSURES AND AUDIT COMMITTEE EFFICIENCY: EVIDENCE FROM MANUFACTURING FIRMS LISTED ON THE BIST*
}

Dr. Melissa Nihal CAGLE

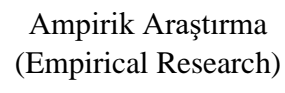

Muhasebe ve Vergi

Uygulamaları Dergisi

Teтmuz 2021; 14 (2): 479-510

\begin{abstract}
Although the International Accounting Standards Board states that over 166 jurisdictions have globally adopted IFRS/IAS, this statement, unfortunately, overlooks the reporting firm's financial statements' actual compliance level. Despite the international accounting communities' continued efforts, there remains a worrying trend of non-compliance within financial statements prepared according to the International Financial Reporting Standards. Serving as a mechanism towards ensuring that the firms' financial reports are understandable, transparent and reliable, and prepared following the current legislation and international accounting standards, the Audit Committee (AC) is uniquely positioned to increase the quality of information produced by organizations. By employing the International Accounting Standard 24 "Related Party Disclosures", this paper aims to empirically measure Turkish manufacturing firms' compliance levels listed on the BIST within 2019. Moreover, the paper attempts to analyze the driving role AC characteristics play in increasing compliance within the firms. It is hoped that the results of this research will hold particular importance for researchers and regulatory agencies in promoting further improvements of the Audit Committee.
\end{abstract}

Keywords: Audit Committee Characteristics, IAS 24, Related Party Disclosures, Disclosure Compliance Analysis, Manufacturing Firms.

JEL Codes: M41, M42, M49.

APA Stili Kaynak Gösterimi:

Cagle, M. (2021). Compliance with IAS 24 Related Party Disclosures and Audit Committee Efficiency: Evidence from Manufacturing Firms Listed on the BIST. Muhasebe ve Vergi Uygulamaları Dergisi. 14 (2), 479-510.

* Makalenin gönderim tarihi: 21.05.2020; Kabul tarihi: 04.01.2021, iThenticate benzerlik oranı \%13

${ }^{a}$ Dokuz Eylül Üniversitesi, Issletme Fakültesi, melissa.cagle@deu.edu.tr

ORCID: 0000-0003-0480-5626.

Muhasebe ve Vergi Uygulamaları Dergisi 


\section{UMS 24 İLISSTKILII TARAF AÇIKLAMALARINA UYUM VE DENETIM KOMITESI VERIMLILIIĞİ: BIST'TE LISTELENMIŞ ŞIRKETLER ÜZERINE AMPIRIK BIR ANALIZ}

\section{$\ddot{\mathrm{oz}}$}

Uluslararası Muhasebe Standartları Kurulu küresel olarak 166 ülkenin UMS/ UFRS'yi benimsemiş olduğunu beyan etsede, firmaların standartlar ile gerçek uyumluluk düzeyi göz ardı edilmektedir. Uluslararası muhasebe topluluklarının tüm çabalarına rağmen standartlara tam uyum sağlanamamış ve dipnotlarda süregelen uyumsuzluk literatürde tartışma konusu olmuştur. Finansal raporların anlaşılabilir, şeffaf ve güvenilir bir şekilde yürürlükteki mevzuata ve uluslararası muhasebe standartlarına uygun hazırlanmasına yönelik önemli bir görev üstlenen Denetim Komitesinin bilgi kalitesini artırma yönünde fayda sağlayacağı ileri sürülmektedir. Uluslararası Muhasebe Standardı 24 "İlişkili Taraf Açıklamalarını" baz alan bu çalıșmada, 2019 yılında BIST'te listelenen imalat şirketlerinin dipnot uyum düzeylerini analiz etmektedir. Buna ek olarak, çalışma şirketlerde uyum düzeyini artırma yönünde Denetim Komitesi karakteristiklerinin rolünü ampirik olarak ölçmeyi amaçlamaktadır. Analiz sonuçlarının Denetim Komitelerinin fonksiyonunun daha da geliştirilmesi amacıyla araştırmacılar ve düzenleyici kurumlar için önem arz edeceği umut edilmektedir.

Anahtar Sözcükler: Denetim Komite Karakteristikleri, UMS 24, İlişkili Taraf Açıklamaları, Dipnot Uyum Analizi, İmalat Şirketleri.

JEL Kodları: M41, M42, M49.

\section{INTRODUCTION ${ }^{1}$}

Since the International Accounting Standards Committee's (IASC) establishment in 1973 and continued efforts as the IASB since 2001, the International Accounting Standards Board has gathered the support of organizations such as the World Bank, International Organization of Securities Commissions (IOSCO), Financial Accounting Standards Board (FASB) and the European Commission. Additionally, numerous countries have taken the necessary steps to adopt the standard-set in one form or another (Nobes, 2006, p.234; Leuz, 2010, p.5). Currently, the Board states that over 166 jurisdictions have globally adopted IFRS/IAS (IASB, 2020, p.1). Unfortunately, this statement overlooks the actual level of compliance within the reporting firm's financial statements themselves. Despite the continued efforts undertaken by the international accounting community since the establishment of the Board, there remains a worrying trend of noncompliance within financial statements prepared according to the International Financial Reporting Standards. Regardless of various countrylevel characteristics such as; the degree of enforcement or oversight (Ahmed et al., 2012; Persaud, 2015; Cafaggi and Renda, 2012; Rechtschaffen, 2007; Laux and Stocken, 2013; Leuz et al., 2008; Leuz,

${ }^{1}$ This paper was completed while the author was a Visiting Scholar at the University of Florida, Warrington College of Business, Fisher School of Accounting. The author was supported by the TÜBİTAK 2219 "International Postdoctoral Research Fellowship Program for Turkish Citizens".

Muhasebe ve Vergi Uygulamaları Dergisi 
2010; Santos et al., 2014; Goh et al., 2016; Hartwig, 2015; Wang, 2018), distinction between civil/common law countries (Santos et al., 2014), developed/emerging market status (Abdullah et al., 2015; Dawd, 2018; Tsalavoutas, 2011; Tsalavoutas and Dionysiou, 2014) geographical region (geographical business diversity) (Cascino and Gassen, 2015), Anglo-Saxon countries (Baboukardos and Rimmel, 2014), EU-membership (Goh et al., 2016; Tsalavoutas, 2011); or firm-level characteristics such as firm CEO/family ownership level (Abdullah et al., 2015; Goh et al., 2016; Tahat et al., 2017; Mgammal et al., 2018), governmental ownership status (Cascino and Gassen, 2015), incentive compensation (Mgammal et al., 2018), firm profit level (Dawd, 2018; Tsalavoutas, 2011), firm size (Bepari et al., 2014; Hartwig, 2015), leverage (Dawd, 2018; Bepari et al., 2014; Hartwig, 2015), liquidity level (Dawd, 2018), firm industry type (Tsalavoutas, 2011; Tahat et al., 2017), non-financial/financial firm distinction (Hartwig, 2015), takeover/mergers attempts (Wang, 2018) or the future prospects of the firm (Hartwig, 2015) countries continue to paint a picture of non-compliance with the international standards. Moreover, this argument is also supported by numerous studies testing the relationship between IFRS implementation practices. For example, the introduction of new accounting measurement and/or recognition requirements (Tsalavoutas, 2011, Baboukardos and Rimmel, 2014), whether or not the reported standards require disclosures that involve high proprietary costs (Tsalavoutas, 2011), financial disclosure length (Santos et al., 2014), the toughness of a particular IFRS/IAS standard (Wang, 2018), initial IFRS adoption year/learning curve (Santos et al., 2014; Mayorga and Sidhu, 2012) and disclosure compliance levels. As supported by these studies, we see that low compliance levels for mandatory IFRS disclosure practices are common for many countries and firms with differing characteristics. Since disclosures are a vital decision-making tool for various user groups, steps need to be taken to reduce the current misrepresentation and/or low disclosure activity of firms (Leuz and Wysocki 2008, p.13, Jackson and Roe, 2009, p.232) and raise disclosure practice to an internationally acceptable and comparable level (Al-Akra et al., 2010, p.171). Thus, this creates motivation to question "what drives higher levels of disclosure compliance?".

Researchers (Agyei-Mensah, 2019a; Kabara et al., 2019; Ernawati and Aryani, 2019) are of the opinion that higher compliance with IFRS can be achieved through an efficient Audit Committee (AC) within organizations. Governed by the requirements put forth by the Corporate Governance (CG) Principles of Turkey [as published by the Turkish Security Exchange Commission (Sermaye Piyasası Kurulu- SEC)] and the 5411 th Turkish Banking Regulation [as published by the Turkish Banking Regulation and Supervision Agency (Bankacillk Düzenleme ve Denetleme KurumuBRSA)], firms with stocks trading on the BIST are obligated to establish an

Muhasebe ve Vergi Uygulamaları Dergisi 
AC consisting of a minimum of two members elected by the Board of Directors. Moreover, committee members are legally obligated to convene every three months and submit an outcome-report to the Board of Directors. The CG principles (published on the $3^{\text {rd }}$ of January 2014, Official Gazette no: 28871) also recommend that at least one-third of the Board of Directors should be composed of independent members (no less than two members). However, the chairman of the committee must be an independent member. Members of the AC should have working knowledge and experience in "accounting, financial reporting, internal control, internal and external audit, risk management, national and international accounting regulations and standards" to effectively perform their duties and functions.

According to CG Principles of Turkey, the AC serves to oversee organizations' internal and external audit processes' efficient and effective operation. The committee bears the responsibility of adding value to the firm and ensuring that internal systems related to accounting, financial reporting, and internal control are conducted in a transparent, functional, and adequate manner on behalf of the Board of Directors. Moreover, the committee is responsible for observing the integrity of the financial information produced, ensuring that the financial reports (and disclosures) are understandable, transparent, reliable, and prepared according to current legislation and international accounting standards. Finally, the AC is charged with resolving any issues about accounting practices and the selection/oversight of the independent audit institution. From analyzing the role of the AC within the organization, it is apparent that they are in a unique position to improve the transparency and integrity of financial information produced by the organization. An efficient AC could potentially serve as a mechanism for increasing standard compliance levels within firms (Agyei-Mensah, 2019a, p.7). This marks the incremental value of this study there is currently a call for research for understanding the relationship between AC characteristics and disclosure compliance. Moreover, this study contributes towards analyzing the effect on mandatory IFRS disclosures as prior researcher (Agyei-Mensah, 2019b; Omran and Abdelrazik, 2013) has focused on voluntary based disclosures in related papers. Finally, researchers (Wang, 2018; Agyei-Mensa, 2019) state there is a lack of 'empirical studies' analyzing comparing the effect of AC characteristics on standard compliance. Coupled with the above-presented arguments, this study will attempt to add to the debate on the role of the AC characteristics in ensuring compliance with mandatory international reporting standards.

The International Accounting Standard 24: "Related Party Disclosures" is taken as a basis to test the standard compliance levels of firms [The standard employed within Turkey is in full compliance with the IAS 24]. The IAS 24 standard was selected for analysis because of its role in "assessing/reporting information for financial information users who need to be aware of the 
possibility that the firm's financial position and profit or loss may have been affected by related parties" (IMS 24, p.1). Thus, it can be argued that the standard provides critical information on the organization's dealings, intending to increase its transparency. Moreover, the standard acts as a bonding mechanism between related parties and the organization (Gordon and Henry, 2005, p.2; Agyei-Mensah, 2019a, p.6), reducing parties' incentive to engage in opportunistic behavior. Finally, the standard's scope ensures that it encompasses a large percentage of operations and is employed under a wide variety of firms. The selection of the standard is further supported by researchers arguing that there is currently a lack of empirical research conducted on "Related Party Disclosures" compliance (Tsalavoutas et al., 2020, p.24). Turkey was selected for the analysis because there is currently a lack of studies analyzing developing countries' compliance.

Use of the disclosure checklist (disclosure index) method was employed to measure the hypotheses, "AC characteristics have a significant positive effect on the IAS 24 disclosure compliance levels of firms". The analysis consisted of the reporting year 2019 and included the mandatory reporting requirements of the IAS 24 standard in effect for that period's annual financial statements. A sample of 174 manufacturing firms (distributed across 9 sub-sectors) annual financial reports were examined via the use of a control checklist that only included the mandatory IAS 24 requirements. In the second stage of the study, a step-wise multiple regression analysis is conducted to test the hypothesis and analyze the driving effect AC characteristics have on IAS 24 compliance levels. Findings suggest that, instead of having a positive effect on compliance levels of firms, AC characteristics (such as; the outcome-reports submitted, physical meetings conducted, committee member days on the job, prior experience) showed a negative and insignificant relationship with the overall compliance levels of disclosures under IAS 24. On the other hand, the AC gender distribution is positively (and significantly) influenced by financial reporting quality. Further analysis was conducted to test whether the Big 4 auditing firms were far more effective in promoting financial reporting compliance than the AC. Interestingly, the findings indicate higher compliance in companies audited by the non- Big 4 auditing firms. It is hoped that the results of this research will hold particular importance for researchers and regulatory agencies in promoting the efficient application of the AC in Turkish manufacturing firms. The rest of the paper is organized as follows. Section 2 addresses the current empirical compliance research conducted on the AC. Section 3 presents detailed information on the methodology. The findings and discussion are summarized under Section 4 and Section 5, respectively.

Section 6 concludes. 


\section{LITERATURE REVIEW}

Agyei-Mensah (2019a) analyzes the relationship between AC characteristics and its influence on disclosure related party information within the annual reports of 30 non-financial firms listed on the Ghana Stock Exchange (120 firm-year observations). The analysis encompasses the period of 2013 to 2016. The researchers employ a disclosure checklist consisting of the reporting requirements identified by the KPMG IAS 24 disclosure checklist. By conducting a multivariate regression analysis, the researchers determine that firms' sample shows low compliance with the standard. The authors argue that a compliance level of $26 \%$ (ranging from $6 \%$ to $55 \%$ ) could be due to a lack of appropriate enforcement mechanisms. By conducting a regression analysis on $\mathrm{AC}$ characteristics (AC meetings, $\mathrm{AC}$ size, independence, financial expertise, ownership concentration, and $\mathrm{AC}$ gender distribution) the researchers determine that although the overall compliance score for these firms is low, compliance increases as AC gender diversity, independence, and ownership concentration as disclosure related party information does. They argue that effective monitoring is achieved when all $\mathrm{AC}$ members are independent, as it reduces the agency problem. Moreover, the authors support that gender diversity within the AC could influence financial reporting quality and increase the sample firms' transparency. Alkurdi et al. (2019) examine the relationship between the Board of Directors' characteristics, the sample firms' transparency, and risk disclosures for Jordan-listed firms between 2008 and 2015. The authors state that the release of risk disclosures are an essential indicator of the transparency, disclosure quality, and the inclination of the organization to protect shareholder interests. The study conducts a regression analysis and determines that 4 characteristics have positively impacted increasing voluntary risk disclosures within the sample. Alkurdi et al. $(2019$, p.4) argue that a large number of members on the board help mitigate the information asymmetry problem, thus leading to more disclosure of information. Regarding the independence of the Board, Alkurdi et al. (2019, p.5) state the higher the number of independent members, the more pressure is put on management to release information. Moreover, the authors argue that (Alkurdi et al., 2019, p.5), if the chief executive officer's duties and the chairman of the Board of Directors are separated, potential conflicts of interest between the two roles could be avoided. Finally, the number of meetings held out throughout the accounting period is argued to reduce the risk of fraud and increase the committee's level of compliance with the reporting standards. When mandatory disclosures are considered, the authors determine that the Board's independent directors and the committee's overall size positively influence disclosures. Finally, firm characteristics such as leverage and firm size are found to be indicators of a higher propensity to publish risk disclosures. Mnif and Znaze (2020) analyze IFRS 7 "Financial Instrument Disclosures" and its inherent

Muhasebe ve Vergi Uygulamaları Dergisi 
relationship with AC characteristics, such as; financial expertise, board size, meeting frequency, separation of duties, and board independence. Employing a disclosure checklist method, their sample consists of 63 Canadian financial firms listed on the Toronto Stock Exchange between 2014 and 2016. The checklist was prepared for each reporting year and contained 128 items. The authors conduct a fixed effect panel regression analysis and determine that, at $77 \%$, the standard's overall compliance levels are low within Canadian firms. Moreover, they determine that the compliance level increases as the board size and independence level rise. On the other hand, AC size, meeting frequency, and separation of duties are not significantly correlated with the disclosure compliance level. Bananuka et al. (2019) aim to analyze IFRS application concerning AC effectiveness in a developing country setting, such as; Uganda. The authors employ a 6-point Likert scale survey conducted on members located within the Association of Microfinance Institutions of Uganda. Bananuka et al. (2019, p.506) define $\mathrm{AC}$ effectiveness as including measures such as $\mathrm{AC}$ independence, financial expertise, annual committee meetings, AC size, and the existence of authority governing the members. The authors base their independent variable selection on its potential effect on reducing earnings management. For example, Bananuka et al. (2019, p.507) argue that AC size, AC meetings, and independence are important indicators working towards increasing the accounting quality within Uganda firms as it serves towards reducing potential problems within the accounting process via increased monitoring capacity. With a sample of 67 members (response rate of 79\%), the authors use a hierarchical regression model to analyze the contribution of AC affectedness in driving IFRS adoption. They determined that the variables have strong explanatory power in that AC characteristics could minimize agency problems within Uganda firms. Upon individually analyzing each independent variable, Bananuka et al. (2019, p.520) find that AC meetings and independence do not govern this relationship. El Mahdy et al. (2019) analyze the effect of AC characteristics (separation of duties and AC financial expertise) on the publication of asymmetric information in US firms listed within the NYSE. The authors collect bid-ask spread information and cross-reference it with the independent variables. The proxy for asymmetric information is measured via the quoted spread, effective spread price impact, and informed trade probability. The information for the analysis is downloaded from the institutional shareholder services and the Compustat databases. The final sample consists of 2398 firms (with 16,793 firm quarter observations) between 2006 and 2007. The authors conduct a regression analysis and determine that the existence of members with financial expertise aid in reducing information asymmetry. Moreover, they find that management's duality mediates the relationship between AC financial expertise and information asymmetry. Stated differently, the authors find a positive and significant relationship 
between the interactions of "separation of duties, information asymmetry, and AC characteristics". The authors argue for the usefulness of regulatory mandates governing $\mathrm{AC}$ characteristics, determined by observing favorable price reaction recorded under the observations.

Talpur et al. (2018) analyze the voluntary disclosures provided by Malaysian listed companies in 2016. The sample consists of 85 companies listed on the exchange from 2012 to 2015 continuously (and with financial statements available each year). The compliance information was hand collected from the annual reports and was cross-referenced with Malaysia's renewed corporate governance code. To determine the influence of AC characteristics (financial expertise, independence, AC size, AC member tenure, multiple directorships, and AC meetings) on the publication level of voluntary disclosures within the sample, the authors conducted a regression model with panel data analysis and measured the influence of changes within the characteristics over 2012 to 2015 . The voluntary data consisted of a corporate governance index constructed by the Malaysian watchdog shareholder group and was coded by employing a disclosure checklists method. The authors argue that the adoption of high-quality standards does not dictate the publication of quality financial statements (Talpur et al., 2018, p.547). As a result, they argued that a transparent AC would help monitor and control business activities and secure minority shareholder interests (Talpur et al., 2018, p.546). Although audit size is argued to be an effective measure for overcoming deep internal issues within the monitoring system and similarly, AC meetings are argued to be a valuable platform for sharing opinion and expertise (Talpur et al., 2018, p.548) - the results of the analysis show that only AC tenure and multiple directorships were associated with increased voluntary disclosures. Ettredge et al. (2011) analyze the compliance with SEC disclosure requirements concerning form $8 \mathrm{~K}$ - item 4, which covers information published upon changing external auditors. The study sample consisted of 128 firms that changed auditors between 2005-2007 but did so while reporting bad news. The paper aims to determine whether or not firm size, corporate governance quality, and bad news are driving factors affecting compliance with the aforementioned mandatory SEC disclosure requirements. The authors determined that firms with low compliance levels had lower quality corporate governance and more bad news disclosed. The authors define corporate governance quality as Board independence, financial expertise, and the committee's size. they argue that broad evidence is available supporting the role of quality corporate governance in generating higher financial reporting (Ettredge et al., 2011, p.9). Finally, the authors defined bad news as an adverse opinion provided on reports within the past two years. For example, whether or not the change and auditors were pre-approved by the Board, disagreements with the former auditor, and reportable events of any disagreement on applying accounting principles. The regression analysis results indicate that

Muhasebe ve Vergi Uygulamaları Dergisi 
non-compliance is related to firm size and corporate governance quality in the absence of bad news. Moreover, they argue that since auditors' changes are challenging affairs for small organizations, the AC's overall strength holds an important role in increasing disclosure compliance. They argue that active AC that frequently meet can encourage further disclosure compliance. Al Sawalqa (2014) analyzes how banks in Jordan comply with the 2007 national corporate goals and disclosures. The researcher analyzes the financial reports of 13 banks within the Amman Stock Exchange. He determines that the compliance for the code within the sample is fairly high, at $90.9 \%$. The calculated compliance rate is then cross-referenced with the information generated from a voluntary disclosure index. The items located under the voluntary index were determined by combining several resources, such as; the instructions of issuing company disclosures within the Jordan Securities Commission, the bank directors' handbook on corporate governance, Jordan banking and companies' law. The author's final voluntary disclosure categories are as follows; corporate strategy, 'AC, Board and management' information and credit risk. The results show that these banks only provide $61.3 \%$ of voluntary disclosures. The author argues that more value should be given to corporate governance to increase disclosures. However, the author states that the low percentage could also result from banks' unwillingness to disclose sensitive and critical information. Alanezi and Albuloush (2011) analyze voluntary AC's implementation (further explained by family members on the Board, industry type, and leverage) and its effect on IFRS compliance concerning mandatory disclosures. The analysis focuses on 68 Kuwait firms listed on the Stock Exchange within the year 2007. The data for the analysis consists of primary data collected directly from the sample (listed within the manufacturing, services, and food industries) in the form of a questionnaire. The regression analysis results show that implementing a voluntary AC within firms has had a positive and significant effect on increasing disclosure level. Contrarily, the authors find that company size, profitability, company age, and ownership structure do not significantly affect the level of disclosures. Moreover, having multiple family members on the Board negatively influences the disclosure level. Agyei-Mensah (2017) analyzes reporting practices concerning IFRS 7 risk disclosures within Ghana firms. The sample comprises 35 firms listed on the Ghana Stock Exchange from 2011 to 2013. The disclosure level for the sample varies between $33 \%$ to $53 \%$. The author argues that good corporate governance practices can increase firm operations' accountability and transparency. As a result, its role in further improving disclosure compliance could not be ignored. Variables such as board size, non-executive directors, institutional ownership, AC independence, firm size, auditor type, leverage, and profitability are considered in relation to IFRS 7 disclosures. The data is hand collected from the sample's annual financial reports, and the disclosure 
checklist method is employed to calculate the disclosure level. A panel data regression analysis indicates a positive relationship between the quality of disclosure and board size. Contrarily, a negative relationship is identified between IFRS 7 disclosures and institutional ownership.

Musleh Al-Sartawi et al. (2016) argues that corporate governance aids in improving the organization's transparency of financial information. Moreover, they put forth that full compliance with the international reporting standards reduces information asymmetry and increases financial information users' confidence while making decisions. The authors conduct a disclosure analysis of 39 firms listed within the Bahrain Bourse in the year 2015. IAS 1 is employed in the review to measure compliance levels within the sample. The independent variables consist of firm characteristics, such as size, age, leverage, profitability, auditor type, and industry. Moreover, the AC characteristics analyzed under the study are the separation of duties, board size, independence, meetings, financial expertise, and ownership structure. The regression analysis results show a positive and significant relationship between corporate governance and the level of disclosure compliance for listed firms. Furthermore, the authors also identify a positive relationship between the type of audit firm and disclosure compliance for IAS 1. Bepari and Mollik (2015) examine the relationship between AC members' financial expertise and the firm's compliance with the IAS 36, specifically the goodwill impairment testing in disclosure requirements. Moreover, they distinguish between Big 4 and non-Big 4 auditors reporting practices. The sample consists of firms listed in the S\&P/ASX 500 between 2006-2009 (firms year observation of 911). A disclosure checklist is prepared on the reporting requirements for goodwill impermeant testing concerning Australian firms. By conducting a multivariate and a fixed effect panel regression, the authors find that although the level of compliance across all firms or auditors is low, there is a significant relationship between the AC financial expertise and goodwill disclosures.

As apparent from the literature covered above, there seems to be a consensus regarding the positive effect of $\mathrm{AC}$ characteristics and their role in increasing disclosure compliance and reporting quality. Regardless, a large percentage of studies conducted on the overall disclosure compliance levels (Schultz and Lopez, 2001; Cairns, 1997; Mayorga and Sidhu, 2012; Street and Gray, 2001; Lopes and Rodrigues, 2006; Marston and Shrives, 1996; Fekete and Matis, 2008; Tsalavoutas et al., 2010; Al-Shiab, 2003) paint a persisting picture of non-compliance in regards to financial statements prepared to employ the use of international reporting standards. Thus, this study attempts to add to the debate on the active role of the AC in improving IFRS application. To test this present opinion, the compliance levels for disclosure requirements of IAS 24 will be analyzed. The following hypothesis will be tested under the paper.

Muhasebe ve Vergi Uygulamaları Dergisi 
COMPLIANCE WITH IAS 24 RELATED PARTY DISCLOSURES AND AUDIT COMMITTEE EFFICIENCY: EVIDENCE FROM MANUFACTURING FIRMS LISTED ON THE BIST

Hypothesis 1: "AC characteristics have a significant positive effect on the IAS 24 disclosure compliance levels of firms".

\section{METHODOLOGY}

The disclosure checklist (disclosure index) method was employed to measure the hypothesis and included the IAS 24 standard requirements in effect for annual financial statements (for the year 2019). Prior to data collection, a pilot test was conducted, and 20 firms were randomly selected and pre-examined in terms of their disclosure format, content, and location. The information collected from the analysis was cross-referenced using the large auditing firms' financial statements templates. The information gathered was then collected under a reference booklet and served as a guideline for coding the IAS 24 disclosure requirements for 2019. A total of 117 criteria were examined for each firm. As several requirements of the IAS 24 cover both the "payable to, and receivable from related parties" (IAS 24 , item 20), several items under the standard were evaluated separately for both groups of transactions. The compliance levels of the sample were coded in an excel file. If the firm complied with the reporting requirement, the firm was recorded as "1", if not, then "0". However, if firm operations were not associated with either of the 117 activities identified under the checklist, the firm was coded as "2" (Taylor et al., 2008, Beattie et al., 2004). It should be noted that it is possible to crosscheck the usage of certain reporting requirements, not only through the disclosures but also from the financial statements, from information on the firm available on the PDP (Kamu Aydınlatma Platformu-PDP) website and from the official website of the organization. Also, as per the reporting requirements, firms are obligated to list under their reports; the standard amendments in use, the standards that have not come into effect and the standards that are not employed because of the firms' operations. The distinction between firms that are liable to report " 1 or 0 " and those that are not "2" is important as it ensures that a firm is not mistakenly coded as "non-compliant".

The annual financial reports of the firms were used in data collection. As the annual reports include the independent auditors' reports, it is assumed that they will reflect the firm's operations more reliably. Thus, the researcher determined which disclosure items were to be coded as "2" under the checklist to the best of their knowledge. The data collected were analyzed using SPSS Version 24. To better analyze and maintain the integrity of the examined criteria, the IAS 24 standard requirements were separated into 9 sub-groups (Al-Shiab, 2003; Tsalavoutas et al., 2010; Street and Gray, 2001), according to content and IAS 24 main-headings and then weighted equally. These sub-groups are as follows; G1 "reporting requirements for

Muhasebe ve Vergi Uygulamaları Dergisi 
key management personnel compensation, and short/long-term, postemployment, termination or share-based benefits", G2 "disclosures regarding the parent", G3 "disclosures regarding entities with joint control or significant influence over the entity", G4 "disclosures regarding subsidiaries", G5 "disclosures regarding associates", G6 "disclosures regarding joint ventures", G7 "disclosures regarding key management personnel of the entity or its parent", G8 "disclosures regarding other related parties" and G9 "disclosures regarding government-related entities". The checklist was later quantified into compliance percentages using a common index formula employed under literature (Taylor et al., 2008; Cooke, 1992; Botosan, 1997; Beattie et al., 2004). First, firms' compliance percentage for sub-groups that were liable to report was calculated. Following this, the overall compliance level per-firm was calculated. Finally, the total compliance level per-firm was divided by the sample size, giving us the overall compliance level for the period. When conducting the analysis, the firms' score initially quoted as "2" was transformed to "1". If a firm is not liable to report any of the 117 individual activities under the standard, it is not held responsible for reporting the requirement. Thus, the firm is technically in compliance with IAS 24, and, rather than remove them from the analysis, the overall compliance score was calculated.

The 2019 financial reports (Financial Disclosures, Statement of Financial Position, Income Statement, and Comprehensive Income Statement) were downloaded from the Public Disclosure Platform (2020) in Turkey. In case the reports weren't accessible from the PDP - the reports were downloaded from the firms' official website. The IAS 24 requirements were downloaded from the Public Oversight Accounting and Auditing Standards Authority (2020) (Kamu Gözetim Kurumu- POAASA) in Turkey. The POAASA was established in the year 2011 (via the 660 Organization and Responsibilities Law) and was granted authority to set/issue accounting standards in compliance with the IFRS/IAS. Compliance with these POAASA publications is mandatory for all firms listed under the BIST. Thus, firms applying the requirements published by the POAASA under their financial statements are considered to be in full compliance with the international standards. The reporting requirements are published under the POAASA in the form of "sets" for each reporting period. These sets are continuously updated according to amendments provided by the IASB and the POAASA. The IAS 24 was initially published under the Official Gazette on the $31^{\text {st }}$ of December 2005 (Official Gazette No. 26040). The standard has consistently adapted updates mandated by the IASB for the IAS 24. Turkey was selected for the analysis as there is currently a lack of studies analyzing the compliance within emerging countries. Firms with accounting periods beginning on the 1st of January were included in the analysis. Firms with a fiscal year-end other than the 31 st of December were excluded from the

Muhasebe ve Vergi Uygulamaları Dergisi 
analysis as it reduces the risk of the compared reports being affected by different underlying economic events. Moreover, it reduces the risk of a "transition gap", where national standards and/or IFRS would come into existence (Barth et al., 2008). The comparison of different versions of the accounting standard would lower the comparability of the findings (Hellman, 2008). Finally, as the annual reports were taken into consideration for this study, it would be some time until the reports for the remaining firms (with fiscal year-end periods other than the $31 \mathrm{st}$ of December) were published (Stenka et al., 2008). As a result, these firms were excluded from the analysis.

Financial firms were also not employed because of the limited sample size under the BIST. The initial sample consisted of 177 firms listed under the manufacturing sector within BIST. However, 3 firms were excluded because the firms had yet to publish their annual 2019 financial statements at the time of the data collection. Thus, bringing down the sample size to 174 , distributed across 9 sub-sectors. This information is summarized in Table 1, below.

Table 1: Sample Size

\begin{tabular}{|l|c|}
\hline Sector & Firms \\
\hline Basic Metal & 18 \\
\hline Other Manufacturing Industry & 1 \\
\hline Food, Beverage and Tobacco & 27 \\
\hline Paper and Paper Products, Printing and Publishing & 13 \\
\hline Chemicals, Petroleum Rubber and Plastic Products & 30 \\
\hline Fabricated Metal Products Machinery Electrical Equipment and Transportation Vehicles & 32 \\
\hline Wood Products and Furniture & 5 \\
\hline Non-Metallic Mineral Products & 26 \\
\hline Textile, Clothing and Leather & 22 \\
\hline Total & $\mathbf{1 7 4}$ \\
\hline
\end{tabular}

In the second stage of the study, a step-wise multiple regression analysis is conducted to test the hypothesis. The purpose of the step-wise multiple regression analysis is to analyze the driving effect of AC characteristics on IAS 24 compliance levels. The analysis will not only shed light on the total effect of the dependent variable [manufacturing firms IAS 24 disclosure compliance levels] when all independent variables [AC meetings, AC reports, $\mathrm{AC}$ financial expertise, $\mathrm{AC}$ gender distribution and $\mathrm{AC}$ prior experience] but it will also enable testing for the effect on the dependent variable of 1 unit change in the independent variable (while controlling for all other independent variables). The aim is to determine the overall fit of the model-testing the inherent relationship between the variables. Control

Muhasebe ve Vergi Uygulamaları Dergisi 
variables such as; firm size (measured as average assets for the years 20182019), liquidity (measured as Current Ratio=Current Assets/Current Liabilities), profitability (measured as Return on Equity=Net Income/ Shareholder Equity and Return on Assets=Net Income/Total Assets) and leverage (measured as Debt to Equity=Total Liabilities/ Shareholder Equity) are also included under the analysis in order to test the relationship. Finally, the model will be extended to test the role of Big 4 auditing firms in promoting financial reporting compliance. The model for the analysis can be found below.

Overall IAS 24 Disclosure Compliance $=\beta_{0}+\beta 1$ Firms Size $+\beta_{2}$ AC Gender Distribution $+\beta_{3} A C$ Meetings $+\beta_{4} A C$ Reports $+\beta_{5}$ AC Financial Expertise $+\beta_{6}$ AC Prior Experience $+\beta_{7}$ Firm Leverage $+\beta_{8}$ Firm Profitability+ $\beta_{9} \quad$ Firm Liquidity+ $\beta_{10} \quad$ Big $4 \quad$ Usage (1)

The information regarding the AC characteristics of the sample firms was hand-collected from the PDP and the official website of the firms. The information regarding each firm listed in BIST is available under the firm chart within the PDP. It is divided between the Summary Information (Notifications from company section), General Information (Scope of activities and independent audit company information, company management, subsidiaries, noncurrent financial assets, financial investments, and miscellaneous sections) and Corporate Governance Information (Board of directors, disclosure and transparency, shareholders sections) pages according to the topic. Table 2 further summarizes the sources for the data employed under the analysis, below.

However, before the analysis, multiple regression assumptions must be tested; normality, linearity, heteroscedasticity, independence of observations, and multicollinearity. Moreover, the data must be screened in detail for the appropriate format, missing data, incorrectly entered data, and any outliers. The dependent variable, "manufacturing firms IAS 24 disclosure compliance levels," is measured on a continuous scale from 0 to 100. Similarly, the independent variables are continuous in nature (interval/ratio). Missing data under $10 \%$ for each individual variable is ignorable (Hair et al., 2014, p.151) and no additional steps need to be taken to correct the discrepancy. If this amount is above $10 \%$, then the observation needs to be excluded from the sample. Upon reviewing the data for missing values, it is determined that the percentage ranges from $11.5 \%$ to $14.9 \%$ for AC characteristics. As mentioned before 20 firms' AC composition could not be located within the PDP, official firm website, or the company prospectus. Moreover, 6 firms' information on AC Meetings and AC Reports were not available on the PDP and the firm's official website. As the data has a missing value above 10 , these observations were removed from the analysis. Thus, bringing the sample size for the regression analysis

Muhasebe ve Vergi Uygulamaları Dergisi 
down to 148. Each variable under the data was next screened for incorrectly entered information (data out of the coded range) using frequency tables. Any available responses outside of the coding manual's scope were crosschecked with the excel file. Finally, the data was screened for outliers using the Mahalanobis Distance method in SPSS. Further screening of the data yielded no incorrectly coded variables or outliers. With a sample size of 148 , the ratio of observations to variables is 1 to 21 . The amount is well above the minimum requirement (100 samples or 20 times the variables) needed for conducting the regression analysis [6 independent and one dependent variable].

Table 2: Data Source

\begin{tabular}{|c|c|}
\hline Information/Data & Source \\
\hline \multicolumn{2}{|c|}{ IAS 24 Disclosure Requirements Checklist } \\
\hline $\begin{array}{l}\text { IAS } 24 \text { disclosure requirements for } \\
\text { the reporting year of } 2019\end{array}$ & POAASA Accounting Standards 2019 Set \\
\hline $\begin{array}{l}\text { IAS } 24 \text { reporting requirements for } \\
\text { government-related entities }\end{array}$ & $\begin{array}{l}\text { Information was cross-referenced by reviewing the organization's } \\
\text { ownership structure under financial statements, the PDP, or the } \\
\text { firms' official website. Moreover, the firm's corporate governance } \\
\text { information and Board of director structure provided valuable } \\
\text { information concerning the relationship between the parties [for } \\
\text { example, whether or not the Turkish Ministry of Treasury and } \\
\text { Finance Privatization Administration (Türkiye Cumhuriyeti Hazine } \\
\text { ve Maliye Bakanlığ Özelleştirme İdaresi Başkanlığ } 1 \text { ) owned } \\
\text { controlling shares of the firm or had a member situated with the } \\
\text { firms' Board of directors]. }\end{array}$ \\
\hline $\begin{array}{l}\text { IAS } 24 \text { reporting requirements for } \\
\text { parents, subsidiaries, associates, key } \\
\text { management personnel, joint } \\
\text { ventures, entities with control over } \\
\text { the organization, and other related } \\
\text { parties }\end{array}$ & $\begin{array}{l}\text { Information was cross-referenced by reviewing the organization's } \\
\text { financial statements and the "General Information" available within } \\
\text { the PDP concerning the firms' relationship with parents, } \\
\text { subsidiaries, associates, joint ventures, and other related parties. It } \\
\text { must be pointed out that information concerning these parties is } \\
\text { also available under the statement of firms' financial position. Thus, } \\
\text { the scope of information available on all of the organization's } \\
\text { dealings allowed the researcher to collect information regarding the } \\
\text { IAS } 24 \text { requirements. }\end{array}$ \\
\hline $\begin{array}{l}\text { IAS } 24 \text { reporting requirements for } \\
\text { key management personnel } \\
\text { compensation, and short/long-term, } \\
\text { post-employment, termination, or } \\
\text { share-based benefits }\end{array}$ & The 2019 financial reports for the sample of firms \\
\hline \multicolumn{2}{|r|}{ AC Characteristics } \\
\hline $\begin{array}{l}\text { AC financial expertise, } \mathrm{AC} \text { size, } \\
\text { Independent } \mathrm{AC} \text { and } \mathrm{AC} \text { Reports }\end{array}$ & PDP or the official website of the firms \\
\hline $\begin{array}{l}\text { AC prior experience, AC Meetings, } \\
\text { and AC Gender Distribution }\end{array}$ & PDP \\
\hline \multicolumn{2}{|r|}{ Control Variables } \\
\hline $\begin{array}{l}\text { Firm Size, Leverage, Liquidity and } \\
\text { Profitability }\end{array}$ & The 2019 financial reports for the sample of firms \\
\hline $\begin{array}{l}\text { Independent Auditing Firm Category } \\
\text { (Big } 4 \text { or not) }\end{array}$ & PDP \\
\hline
\end{tabular}


A Shapiro-Wilk test ( $p>05)$ and a visual inspection of the histograms showed no significant departure from normality for each variable. The significance is above 0.05 (alpha level), and thus, the variables are normally distributed. With a skewness and kurtosis in an appropriate range of $1.96<\mathrm{K}, \mathrm{S}<+1.96$, the variables have a bell-shaped curve and are not skewed or kurtotic. Finally, the variables are tested for multivariate normality, and the studentized residuals are found to be normal as a result of the ShapiroWilk's test $(\mathrm{p}>.05)$. Following this, the correlation structure of the variables is calculated using Pearson correlation. The variables' correlation structure provides insights into how relationships can change once we control other model variables. The results of the analysis are summarized as follows; firm size is negatively correlated with the overall compliance level $(\mathrm{r}(148)=-.279, \mathrm{p}<.001)$, while there is a positive correlation between the AC gender distribution and the overall compliance levels $(\mathrm{r}(148)=.198, \mathrm{p}<$ .05). Moreover, the findings indicate higher compliance in companies audited by the non- Big 4 auditing firms. Stated differently, the results of the Pearson correlation show that there is a negative, significant relationship between usage of Big 4 auditing firms and IAS 24 disclosure compliance $(\mathrm{r}(148)=-.162, \mathrm{p}<.005)$. This result is counterintuitive to what is argued under the current disclosure literature. The study results show that as Big 4 auditing firms' usage increases, IAS 24 compliance levels in manufacturing firms decreases. A Pearson correlation analysis was conducted on the independent variables as bivariate correlations of 0.70 or higher may result in multicollinearity issues. Multicollinearity refers to the situation in which the independent/predictor variables are highly correlated, and there is overlap or sharing of predictive power. If the Multicollinearity is high, none of the predictor variables might significantly impact predicting the dependent variable. The results show that there is no problem indicative of multicollinearity between the variables. Only AC Reports and AC Meetings are found to be correlated $(\mathrm{r}(148)=.683, \mathrm{p}<.0001)$

Testing for the linearity of the relationship between the dependent and independent variables yields similar results. A scatter plot between the standardized residuals and the standardized predicted variables and a Normal P-P plot regression of the standardized residuals is employed to depict the relationship. The scatter plots between the variables were situated between -3 to +3 with no points falling out either on the $x$ or $y$-axes. The Normal P-P plot, on the other hand, shows that the data points generally lie on a straight line. Thus, it can be argued from the conducted tests that the variables are linear. The cook's distance also shows a maximum value of 0.126 , well below the cut-off point of 1 ( $\min =0.00, \max =0.126$, mean $=0.008$, $\mathrm{stD}=0.018, \mathrm{~N}=148$ ). The Durbin Watson analysis is also employed to test for the independence of observations (value $=2.125$ ). Field (2009) argues that a value between $1.5<$ D.W. $<2.5$ indicates no correlation. As a result, it is possible to state that there is no serial correlation issue

Muhasebe ve Vergi Uygulamaları Dergisi 
within the observations. Finally, the heteroscedasticity test of BreuschPagan Godfrey is conducted under EViews, as SPSS currently does not allow testing for the assumption without macros' aid (Daryanto, 2018, p.1). The probability chi-square for the variables shows that the $\mathrm{p}$-value is above 0.05 at 0.24 and no heteroscedasticity issue is determined. The assumptions tested above indicate that the data does not violate the requirements for conducting a step-wise multiple regression analysis.

\section{RESULTS}

The results section will initially present information regarding the descriptive statistics of the variables employed under both the compliance and regression analysis. Following this, the IAS 24 disclosure compliance analysis results will be presented by considering the sub-groups of the reporting requirements and the sectors. Finally, the results of the step-wise multiple regression analysis will be presented. As mentioned before, AC information was hand collected from the PDP or the firms' official website. This information also included the working fields of individuals employed as the AC. A visual representation of the AC background is presented below in Figure 1. The pie chart shows that the $\mathrm{AC}$ of manufacturing firms in Turkey comprises of individuals from various backgrounds. From bureaucrats to teachers', individuals employed as AC members for BIST manufacturing firms cover a diverse field. At 47\%, business and management professionals make up nearly half of the AC sample. However, it must be noted that further information on individuals listed under this category is not available on the PDP. Stated differently, the platform does not provide information on the individual's educational background or previous occupation now working as a manager.

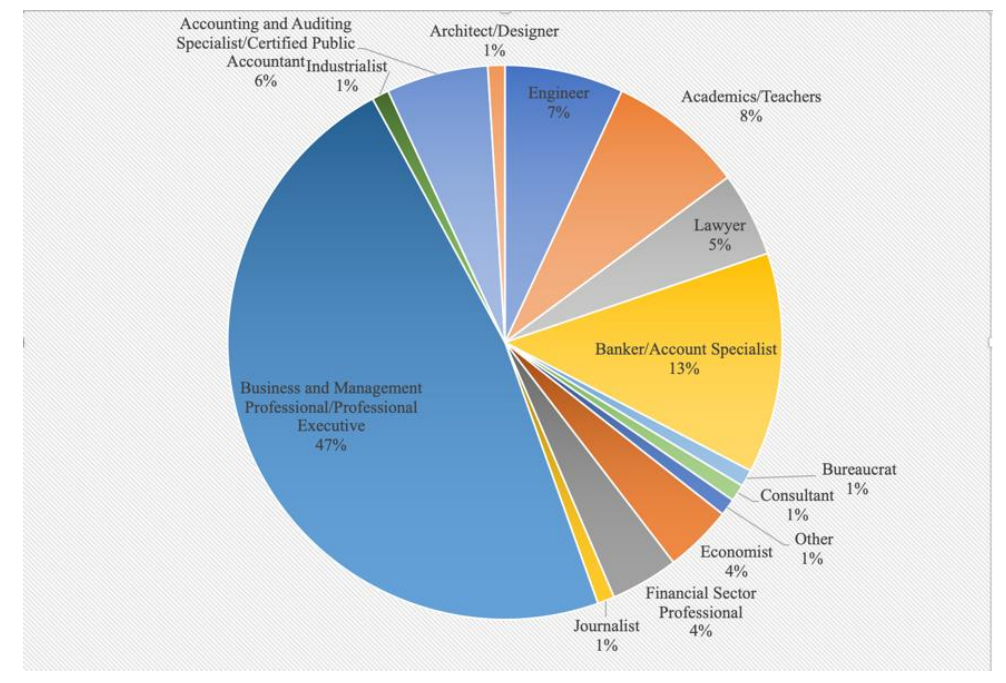

Figure 1: AC Area of Employment 
Although coded as "engineer" under the pie chart, Individuals currently working as AC members consist of mechanical, industrial, electronic, and mining engineers. The information was coded under one item to provide interpretable information on the occupancy of these individuals. The second-highest field is bankers and account specialists at $13 \%$. However, when this information is considered with financial sector professionals (at $4 \%$ ), and accounting/audit specialists and certified public accountants (at $6 \%$ ) it can be argued that individuals coming from a background of accounting/finance make up the second-highest percentage of individuals within the BIST manufacturing firms (at 23\%). Table 3 provides detailed information on the independent variable composition distributed across each sector. Overall, the AC meetings organized within the accounting period and the outcome reports submitted to the Board of Directors are slightly above the Turkish SEC's minimum standards within the corporate governance principles. Moreover, nearly all sectors have a financial expert employed within the audits committee. Stated differently, nearly all sectors are above 50\% regarding the AC financial expert variable. This indicator is deemed essential for ensuring the transparency of information generated by the firm. The only sector scoring below the threshold is the "Paper and Paper Products, Printing and Publishing" industry within Turkey (at 40\%). $\mathrm{AC}$ gender distribution is found to range between $8 \%$ to $25 \%$ for the sample of firms. This shows that a higher percentage of men serve as AC members within Turkey. With only one firm listed under the "other manufacturing industry" sector, the single firm has an all-man AC employed under the organization. The AC prior experience (determined as days served on the committee) remains consistently high across each sector.

Table 3: Sector Average of AC Characteristics

\begin{tabular}{|l|l|l|l|l|l|}
\hline & $\begin{array}{l}\text { AC Gender } \\
\text { Distribution* }\end{array}$ & $\begin{array}{l}\text { AC Financial } \\
\text { Expertise }\end{array}$ & $\begin{array}{l}\text { AC Meetings } \\
\text { (times)** }\end{array}$ & $\begin{array}{l}\text { AC Prior Experience } \\
\text { (days)** }\end{array}$ & $\begin{array}{l}\text { AC Reports } \\
\text { (times)** }\end{array}$ \\
\hline Basic Metal & 0.14 & 0.56 & 5 & 806 & 4 \\
\hline Other & 0 & 1 & 4 & 759 & 4 \\
\hline Food & 0.17 & 0.50 & 5 & 1052 & 4 \\
\hline Paper & 0.08 & 0.40 & 5 & 880 & 4 \\
\hline Chemicals & 0.17 & 0.65 & 5 & 776 & 6 \\
\hline $\begin{array}{l}\text { Fabricated } \\
\text { Metal }\end{array}$ & 0.21 & 0.63 & 5 & 704 & 5 \\
\hline $\begin{array}{l}\text { Wood Products } \\
\text { and }\end{array}$ & 0.25 & 0.75 & 6 & 629 & 5 \\
\hline $\begin{array}{l}\text { Non-Metallic } \\
\text { Mineral }\end{array}$ & 0.17 & 0.81 & 5 & 611 & 4 \\
\hline Textile & 0.22 & 0.55 & 6 & 786 & 5 \\
\hline
\end{tabular}

*Provides information on the percentage of women employed under the AC. The percentage is employed in calculating gender distribution within $\mathrm{AC}$.

**Rounded to the nearest decimal. 
Several problematic issues were also determined under the data collection process. An overview of the independent accounting committee and AC size data collected for the sample indicated little variation between the variables. As mentioned before, the requirements put forth by the SEC in Turkey dictates that the AC should maintain a minimum of two members. Interestingly, many manufacturing firms (\%97) listed on the BIST within the year 2019 have chosen only to uphold the organization's minimum requirements. Out of 174 firms listed within the sector, only six organizations have $3 \mathrm{AC}$ members. It is worrying to note that 20 firms listed in the BIST manufacturing sector do not seem to have formed an AC at all. With SEC also recommending that at least one-third of the Board of Directors should be composed of independent members (no less than two members), it is not surprising that nearly all firms with an AC have scored close to $100 \%$ for independence. The deviation results from 7 firms that choose not to abide by the SEC's recommendation and elected less than two independent members to their committee. As a result, the "AC Size" and "Independent $\mathrm{AC}$ " were removed from the analysis.

The results for the disclosure compliance analysis are as follows. The IAS 24 disclosure compliance scores were calculated for 174 Turkish manufacturing firms. The results of the study indicate that overall compliance for the standard is $70.8 \%$ within Turkey. A score of $70.8 \%$ is relatively low for IFRS disclosure compliance (Tsalavoutas et al., 2020). This finding is reflective of the current "non-compliance argument" within the literature. The results for each sector are provided in Table 4, below.

Table 4: Overall IAS 24 Compliance Scores per Sector

\begin{tabular}{|l|c|}
\hline Sectors & Compliance \\
\hline Basic Metal & 0.6901 \\
\hline Other Manufacturing Industry & 0.5002 \\
\hline Food, Beverage, and Tobacco & 0.7525 \\
\hline Paper and Paper Products, Printing and Publishing & 0.7010 \\
\hline Chemicals, Petroleum Rubber and Plastic Products & 0.7224 \\
\hline Fabricated Metal Products Machinery Electrical Equipment and Transportation Vehicles & 0.7180 \\
\hline Wood Products and Furniture & 0.7157 \\
\hline Non-Metallic Mineral Products & 0.6552 \\
\hline Textile, Clothing, and Leather & 0.7115 \\
\hline Total & $\mathbf{0 . 7 0 8 4}$ \\
\hline
\end{tabular}

A visual analysis of Table 4 shows that the sector with the lowest compliance score is the "Other Manufacturing Industry". However, as stated before, this industry only contains one firm listed under the analysis. As a result, it can be argued that the sector with the actual lowest compliance 
score, with 26 firms, is the "Non-Metallic Mineral Products" industry (at $66 \%$ ). Contrarily, the industry with the highest compliance scores is "Food, Beverage and Tobacco" at 75\% (with 27 firms) and "Chemicals, Petroleum Rubber and Plastic Products" at 72\% (with 30 firms).

The compliance score distributed across each subgroups and sectors is provided in Table 5. According to the analysis results, it is determined that firms have complied more with the reporting requirements of "governmentrelated entities" in IAS 24. At 95\%, the subgroup has the highest compliance rate, which is similarly distributed across each sector. The sector with the lowest government-related entity disclosures is the "Wood Products and Furniture" industry at $80 \%$. The second highest compliance rate goes to the subgroup "entities with joint control or significant influence" at 93\%. The IAS 24 subgroup that has the lowest scores is the disclosures concerning "Other Related Parties". According to the analysis, it is determined that manufacturing firms listed on the BIST within the year 2019 only reported $30 \%$ of the mandatory disclosures. The low reporting rate is consistent for all industries involved in the analysis, with a compliance percentage ranging from $11 \%$ to $36 \%$.

Table 5: Compliance Distributed Across Each Sub-Grouping and Sector*

\begin{tabular}{|l|l|l|l|l|l|l|l|}
\hline Sectors & $\begin{array}{l}\text { Govern. } \\
\text { Rel. } \\
\text { Entities }\end{array}$ & $\begin{array}{l}\text { Other } \\
\text { Rel. } \\
\text { Parties }\end{array}$ & Assoc. & Subsid. & $\begin{array}{l}\text { Entities } \\
\text { with joint } \\
\text { control or } \\
\text { sig. } \\
\text { influence }\end{array}$ & Parent & $\begin{array}{l}\text { Key man. } \\
\text { personnel } \\
\text { comp. and } \\
\text { employee } \\
\text { benefits }\end{array}$ \\
\hline Basic Metal & 0.9259 & 0.3519 & 0.5864 & 0.5760 & 0.8519 & 0.7056 & 0.8333 \\
\hline Other & 1.0000 & 0.1111 & 0.1111 & 1.0000 & 0.2222 & 0.2000 & 0.8571 \\
\hline Food & 1.0000 & 0.3374 & 0.8272 & 0.6062 & 0.9259 & 0.7667 & 0.8042 \\
\hline Paper & 1.0000 & 0.2735 & 0.6581 & 0.6154 & 0.9231 & 0.5692 & 0.8681 \\
\hline Chemicals & 0.9000 & 0.3593 & 0.7667 & 0.5456 & 0.9185 & 0.7717 & 0.7952 \\
\hline Fabricated Metal & 1.0000 & 0.2778 & 0.6910 & 0.5280 & 0.9688 & 0.7219 & 0.8393 \\
\hline Wood Products & 0.8000 & 0.2667 & 0.5778 & 0.6000 & 1.0000 & 0.8800 & 0.8857 \\
\hline $\begin{array}{l}\text { Non-Metallic } \\
\text { Mineral }\end{array}$ & 0.8974 & 0.2863 & 0.5085 & 0.5850 & 0.9231 & 0.5404 & 0.8462 \\
\hline Textile & 1.0000 & 0.2677 & 0.5909 & 0.5622 & 0.9646 & 0.8159 & 0.7792 \\
\hline Total & $\mathbf{0 . 9 5 4 0}$ & $\mathbf{0 . 3 0 7 2}$ & $\mathbf{0 . 6 6 5 4}$ & $\mathbf{0 . 5 7 2 3}$ & $\mathbf{0 . 9 2 7 2}$ & $\mathbf{0 . 7 1 0 6}$ & $\mathbf{0 . 8 2 2 7}$ \\
\hline
\end{tabular}

*The G6 and G7 sub-groups were outside the scope of operations for the firms and were thus excluded from the table.

Table 6 is presented as an example of the coding technique employed in the study. 10 criteria were selected out of the 117 items coded under the analysis. The lowest item quoted within the whole sample is presented below and concerns "key management personnel compensation as employee

Muhasebe ve Vergi Uygulamaları Dergisi 
share-based payment" (at 9\% compliance). This is interesting as the Turkish SEC has closely monitored all key management compensation items since 2008. Contrarily, other disclosures related to key management compensation such as, employee termination benefits (at 90\%) or long term benefits (at $89 \%$ ) have higher compliance rates. The overall highest scoring item within the 117 criteria coded is the IAS 24 disclosure requirement concerning "amount of the transactions between entities with joint control" at $96 \%$. Further information regarding individual criteria is provided under the Discussion section.

Table 6: Select Examples of Items Coded Under the Analysis and Compliance Score

\begin{tabular}{|l|c|}
\hline IAS 24 Disclosure Requirement & Score \\
\hline Key management personnel compensation as employee termination benefits & 0.90 \\
\hline $\begin{array}{l}\text { Relationships between a parent and its subsidiaries shall be disclosed irrespective of whether there } \\
\text { have been transactions between them }\end{array}$ & 0.64 \\
\hline Key management personnel compensation as employee share-based payment & 0.09 \\
\hline Discloser of the name of the parent & 0.93 \\
\hline Amount of the transactions between entities with joint control & 0.96 \\
\hline $\begin{array}{l}\text { Whether or not the number of outstanding balances between subsidiaries and the firm is secured } \\
\text { transactions }\end{array}$ & 0.48 \\
\hline Details of any guarantees given or received for transactions between the associate and the firm & 0.52 \\
\hline $\begin{array}{l}\text { Expenses recognized during the period in respect of bad or doubtful debts due from related } \\
\text { parties' transactions between the parent and firm }\end{array}$ & 0.63 \\
\hline Key management personnel compensation as long-term benefits & 0.89 \\
\hline The nature of the consideration to be provided in the settlement between subsidiaries and the firm & 0.41 \\
\hline
\end{tabular}

A step-wise multiple regression was carried out to analyze the driving effect of AC characteristics on IAS 24 compliance levels. The analysis shows that not all independent variables had a significant $(\mathrm{p}<.001)$ zero-order correlation with the dependent variable. The results of the regression analysis show that only the firm size (-.279) and AC gender distribution (.198) variables had significant $(\mathrm{p}<.05)$ partial effects in the full model. Next, we analyze the $\mathrm{R}^{2}$ and adjusted $\mathrm{R}^{2}$ findings, which provide information on the overall strength of the relationship between the combined independent and dependent variables. The two-predictor model accounted for $9.7 \%$ of the variance (Adj $\mathrm{R}^{2}=.097, \mathrm{R}^{2}=.109$ ) in the overall IAS 24 compliance. Although there is evidence of a relationship between the employed variable, these results indicate that the model is weak, albeit significant, predictor (Moore et al., 2013). Testing for the analysis of variance provides additional information regarding the predictive capabilities of the model. As the ANOVA results show a significance value of less than $\mathrm{p}<0.001$, this is indicative that the regression model

Muhasebe ve Vergi Uygulamaları Dergisi 
significantly predicts the overall compliance scores $\mathrm{F}(2,146)=8.912$, $\mathrm{p}<0.001$. The variables' coefficients are calculated to identify how individual predictor variables have contributed to the model. Reflecting on the initial regression analysis results, the coefficients' results show that firm size $(p=.001)$ and AC gender distribution $(p=.025)$ have significantly contributed to the model. Moreover, the model's unstandardized beta coefficients show that while firm size has a negative relationship with the dependent variable, AC gender distribution has a positive relationship. Stated differently, as firm size increases for individual observations, IAS 24 disclosure compliance reduces. Moreover, as gender distribution within the AC increase, the compliance level gets higher. The unstandardized beta coefficients also reflect the degree to which they influence the dependent variable if the other independent variables' effect is held constant. For example, as AC gender distribution increases by 1\%, the overall IAS 24 compliance level for firms goes up $0.78 \%$. However, the unstandardized beta coefficients for firms' size do not yield meaningful results as the $1 \%$ increase in firms' size results in less than $1 \%$ increase in the dependent variable. The results of the regression analysis are tabularized below in Table 7 . The results presented above are discussed in detail within the following section.

Table 7: Summarization of Regression Analysis

\begin{tabular}{|c|c|c|c|c|c|c|c|c|c|c|c|c|c|}
\hline \multicolumn{14}{|c|}{ Model Summary } \\
\hline Model & $\mathbf{R}$ & \multicolumn{2}{|l|}{$\mathbf{R}^{2}$} & \multicolumn{2}{|c|}{ Adj. $\mathbf{R}^{2}$} & \multicolumn{2}{|c|}{$\begin{array}{l}\text { Std. Error of } \\
\text { the Estimate }\end{array}$} & \multicolumn{3}{|c|}{$\mathbf{R}^{2}$ Change } & \multicolumn{2}{|c|}{ F Change } & $\begin{array}{l}\text { Sig. F } \\
\text { Change }\end{array}$ \\
\hline $1^{\mathrm{a}}$ & .331 & \multicolumn{2}{|c|}{.109} & \multicolumn{2}{|l|}{.097} & \multicolumn{2}{|c|}{.11509} & \multicolumn{3}{|c|}{.032} & \multicolumn{2}{|l|}{5.148} & 0.25 \\
\hline \multicolumn{14}{|c|}{ a. Predictors: (Constant), Firm Size and AC Gender Distribution } \\
\hline \multicolumn{14}{|l|}{ ANOVA } \\
\hline & & \multicolumn{3}{|c|}{$\begin{array}{l}\text { Sum of } \\
\text { Squares }\end{array}$} & \multicolumn{3}{|l|}{ df } & \multicolumn{2}{|c|}{$\begin{array}{l}\text { Mean } \\
\text { Square }\end{array}$} & \multicolumn{2}{|l|}{$\mathbf{F}$} & \multicolumn{2}{|l|}{ Sig. } \\
\hline \multicolumn{2}{|l|}{ Regression } & \multicolumn{3}{|c|}{.236} & \multicolumn{3}{|l|}{2} & \multicolumn{2}{|c|}{.118} & \multicolumn{2}{|l|}{8.912} & \multicolumn{2}{|l|}{$.000^{\mathrm{a}}$} \\
\hline \multicolumn{2}{|l|}{ Residual } & \multicolumn{3}{|c|}{1.921} & \multicolumn{3}{|l|}{146} & \multicolumn{2}{|c|}{.013} & \multicolumn{2}{|l|}{ 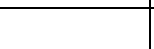 } & \\
\hline \multicolumn{2}{|l|}{ Total } & \multicolumn{3}{|c|}{2.157} & \multicolumn{3}{|l|}{148} & & & & & & \\
\hline a. Predictor & s: (Constant & , Fi & $\mathrm{m} \mathrm{Siz}$ & ee and & $\mathrm{ACC}$ & ender & istributi & & & & & & \\
\hline Coefficient & & & & & & & & & & & & & \\
\hline & $\begin{array}{l}\text { Unstand } \\
\beta\end{array}$ & & $\begin{array}{l}\text { Coef } \\
\text { Std. } \\
\text { Erro }\end{array}$ & & $\begin{array}{l}\text { Stan } \\
\text { Coef } \\
\text { Beta }\end{array}$ & $\begin{array}{l}\text { d. d. } \\
\text { f. }\end{array}$ & $\mathbf{t}$ & & Sig. & $\begin{array}{l}\mathrm{Z} . \\
\text { or }\end{array}$ & der & $\begin{array}{l}\text { Partia } \\
\text { l }\end{array}$ & Part \\
\hline Constant & .698 & & .012 & & & & 58.643 & & .000 & & & & \\
\hline $\begin{array}{l}\text { Firm } \\
\text { Size }\end{array}$ & $\begin{array}{l}-4.314 \mathrm{E}- \\
12\end{array}$ & & .000 & & -.266 & & -3.381 & & .001 & & 279 & -.270 & -.265 \\
\hline $\begin{array}{l}\text { AC } \\
\text { Gender } \\
\text { Distrib. }\end{array}$ & 0.78 & & .034 & & .178 & & 2.269 & & .025 & & 98 & .185 & .178 \\
\hline
\end{tabular}

Muhasebe ve Vergi Uygulamaları Dergisi 
COMPLIANCE WITH IAS 24 RELATED PARTY DISCLOSURES AND AUDIT COMMITTEE EFFICIENCY: EVIDENCE FROM MANUFACTURING FIRMS LISTED ON THE BIST

\section{DISCUSSION}

The study aimed to analyze the IAS 24 disclosure compliance levels for manufacturing firms listed on the BIST within 2019. The analysis was conducted via a disclosure checklist method composed of the IAS 24 "Related Party Disclosures" standard reporting requirements listed on the Turkish POAASA. Firms quoted on the BIST are legally obligated to abide by the reporting requirements published by the POAASA, which are in full compliance with the IFRS/IAS. Each item listed on the IAS 24 was carefully coded, and the annual financial reports for 174 manufacturing firms were analyzed to determine the overall compliance level with the standard. The results indicate low compliance (at 70.8\%) with the standard (Tsalavoutas et al., 2020). This finding is reflective of the current "noncompliance argument" within the international literature. Regardless of the firm, country, or IFRS implementation characteristics, the disclosures prepared by firms according to the international standards suffer from misrepresentation and/or low disclosure activity. As disclosures are a vital decision-making tool for various user groups, steps need to be taken to raise disclosure practice to an internationally acceptable and comparable level. As a result, this paper aimed to determine whether or not the firms' AC [which ensures that the firms' internal systems related to accounting, financial reporting, and internal control are conducted in a transparent, functional, and adequate manner on behalf of the Board of Directors] drives higher levels of disclosure compliance.

Under the first step of the analysis, the compliance scores across each sector and sub-group are calculated. The sector with the lowest compliance score was the "other manufacturing industry"; however, only one firm is listed under this sector. As a result, it can be argued that the industry with the lowest compliance score is the " Non-Metallic Mineral Products" at 66\% (with 26 firms). On the other hand, the industries with the highest compliance scores are the "Food, Beverage and Tobacco" and "Chemicals, Petroleum Rubber and Plastic Products" at 75\% (27 firms) and 72\% (30 firms), respectively. As both of the food and chemical industries maintain strict quality management, diligent recordkeeping and are closely monitored by national regulatory agencies- it is not surprising that both of these industries have higher compliance scores than other sectors (Davies, 1983, p.41). Regulatory agencies regularly audit both of these industries to ensure that they maintain health-code and safety requirements. As a result, it could be argued that they are used to reporting information to maintain good relations with their stakeholders. Finally, this argument is in line with the Alanezi and Albuloushi (2011) findings, who state that there are significant differences across sectors in IFRS-required disclosure compliance.

Muhasebe ve Vergi Uygulamaları Dergisi 
When compliance is measured across each group's reporting requirement under IAS 24, it is determined that "Government-Related Entities" (95\%) and "Entities with joint control or significant influence" (93\%) are the highest reported items under the standard. For government-related entities, nearly all firms are in full compliance. On the other hand, the sector with the lowest score for this grouping is the "Wood Products and Furniture" industry (at $80 \%$ ). This is a crucial disclosure item that provides information on the strength of control or significant influence the government has on the reporting entity (IAS 24, p.6). Thus, full compliance is an essential indicator that the firm's financial statements have not been affected by the existence of transactions or commitments. Another highly reported subgroup consists of key management information. This group's results could be explained by the steps taken by the Turkish SEC in the past to increase the amount of information published by firms listed on the BIST. In the year 2008, the SEC announced that higher monitoring levels for disclosures related to key management personnel would be put into place. The SEC reported that current compliance with the international standards was low for key management information and that they would be taking steps to ensure compliance with the international reporting standards (as reported under the 26th of December 2008 communiqué, no: 2008/51). Soon after, the SEC launched an investigation into the financial statements of firms quoted on the exchange and identified firms that were not in compliance with the reporting standards. These firms were issued an official warning and charged a monetary fine. Thus, a higher compliance rate for key management compensation (at 97\% of the sample firms) is expected. Similarly, items such as short-term benefits for employees (95\%), postemployment benefits (89\%), long term benefits (95\%), and termination benefits $(90 \%)$ are equally reported in higher amounts. The only key management item that seems to have a low reporting rate is the information concerning share-based payment $(9 \%)$. As a result, this paper recommends that the SEC widens its 2008 communique scope to include reporting recommendations for share-based payments. Continuing the assessment of individual reporting items for IAS 24, it can also be argued that manufacturing firms have failed to provide information regarding the terms and conditions for outstanding balances or commitments, whether or not they are secured, or any details of guarantees given/received. Moreover, information on provisions for doubtful debts and expenses recognized during the period for bad/doubtful debts reduces the overall compliance rate for IAS 24. The lack of information provided for the above-stated items is constant for parents, entities with joint control or significant influence, subsidiaries, and associate's in other related parties. Stated differently, the related parties analyzed under this paper all equally have an issue in reporting the above-stated items. 
Another issue identified under the analysis is the lack of information concerning contract details. For example, IAS 24 states that any related party transaction covered within the accounting period should be disclosed with additional details concerning its nature, total commitment or transaction amounts, and outstanding balances. The standard requires this information to allow the user to further understand the related party's potential effect on its financial statements. When the sample's financial statements are analyzed, it is determined that firms choose to report the outstanding balance regarding the transaction solely. Unfortunately, this issue holds constant for each related party reported under IAS 24. Finally, the lowest compliance group is the "other related party disclosures" at $30 \%$. This result holds constant for each sector within the sample.

The second part of the analysis focuses on the AC composition for manufacturing firms quoted on the BIST. Upon analyzing the work field for the current AC sample, it is apparent that most members consist of business managers. Although, as mentioned before, little information is provided on these managers' educational background/prior experience. The second highest group within the $\mathrm{AC}$ work field consists of individuals from the accounting and finance sector. The group includes; certified public accountants, accounting and audit professionals, bankers, and account specialists. This complies with the corporate governance principles published by the SEC. According to the SEC, individuals working as audit committee members must have the necessary educational background to effectively serve and oversee internal systems' operations relating to accounting and financial reporting. The auditing committee serves as a mechanism for improving the transparency and integrity of the organization's financial information. As a result, the SEC mandates that they must have the background to provide these functions. However, upon closer examination of the AC characteristics of the sample, it is determined that 20 firms have not provided any information regarding their AC on the PDP or their official website. An additional search of any communique published by the firm on the PDP or their official firm websites also yielded similar results. As a result, it can be argued that these firms have neglected to comply with the SEC corporate governance principles and have not formed an AC. Moreover, 7 firms within the sample have independent AC members below the required 1/3 threshold. Out of the 174 firms examined, only 6 organizations have AC members above this threshold. Interestingly, it seems that a higher percentage of manufacturing firms listed on the BIST within the year 2019 has chosen only to uphold the minimum requirements put forth by the SEC. Unfortunately, this sets a dangerous precedent for Turkish manufacturing firms as it shows that they are only abiding by the minimum requirements for the $\mathrm{AC}$, further indicating that the committee's function might only be to ward off the scrutiny of the SEC. Further examining the raw data concerning $\mathrm{AC}$ characteristics, it is determined that two firms have 
reported that they did not conduct any AC meetings for the year 2019 . Moreover, 7 firms reported that although they had meetings, it was below the minimum threshold (of 4) set by the SEC. Similarly, another eight firms reported that they did not submit any reports to the Board of Directors on the AC's activities. Although the SEC is unclear whether or not a report should be submitted after each meeting, another 10 firms reported that they submitted reports below 4 .

An inefficient $\mathrm{AC}$ within firms are more liable to miss serious accounting violations. As mentioned before, the $\mathrm{AC}$ is an important feature that serves to increase the internal systems' transparency and efficiency. Without this mechanism, the information provided by the organization is liable for questioning. Thus, this paper's recommendation is to increase monitoring concerning the corporate governance principles for firms listed on the BIST. Regarding the regression analysis results, it is determined that AC meetings, $\mathrm{AC}$ reports, prior experience, financial expertise, firm liquidity, profitability and leverage do not have a significant relationship with the compliance level. These results offer supportive evidence for prior research conducted on AC characteristics (Talpur et al., 2018; Agyei-Mensah, 2019a; Mnif and Znaze, 2020; Talpur et al., 2018; Bananuka et al., 2019). Only AC gender distribution plays a driving role in increasing compliance within the sample. The analysis shows that a $0.78 \%$ increase in compliance could be attributed to a $1 \%$ increase in AC gender distribution. Stated differently, as AC gender distribution increases by $1 \%$, the overall IAS 24 compliance level for firms increases by $0.78 \%$. This argument is supported by Agyei-Mensah (2019a), who similarly argues that $\mathrm{AC}$ gender distribution aids in influencing the quality of financial reporting. When analyzing the results of the correlation analysis, it is determined that Big 4 auditing firms were far more effective in promoting financial reporting compliance than the AC characteristics. The results show that, contrary to what is argued under the literature (Musleh AlSartawi et al., 2016), firm size and the involvement of Big 4 auditing firms reduce the overall IAS 24 compliance levels of the sample. Firms of a larger size are argued to have more resources to provide effective monitoring (Ettredge et al., 2011). Moreover, Big 4 is argued to have an incentive to signal that their clients have a higher degree of disclosure compliance with the international standards and an incentive to protect their reputation (Mollik and Bepari, 2014; Agyei-Mensah, 2019a). However, counterintuitively, the Pearson correlation analysis shows there is a negative, significant relationship between usage of Big 4 auditing firms, firm size and IAS 24 disclosure compliance. When the concentration of Big 4 auditing firms is analyzed for each sector, it is determined that the "NonMetallic Mineral" industry has the highest concentration in comparison to other sectors ( $73 \%$ of auditing firms employed within this sector is Big 4). Interestingly, this sector is also one of the lowest scoring sectors regarding disclosure compliance (at 65\%). The second-highest Big 4 usage sector is

Muhasebe ve Vergi Uygulamaları Dergisi 
the "Paper and Paper Products, Printing and Publishing" at 61\%. This industry has an overall compliance level of $70 \%$. The results also show that Big 4 expertise and concentration within sectors does not lead to higher compliance.

\section{CONCLUSION}

This study offers supportive evidence that compliance for IAS 24 disclosures is low for manufacturing firms in Turkey. Out of the AC characteristics tested [AC meetings, $\mathrm{AC}$ reports, $\mathrm{AC}$ financial expertise, $\mathrm{AC}$ gender distribution, AC prior experience, firm size (measured as average assets for the years 2018-2019)], profitability, leverage and liquidity only AC gender distribution positively contributed towards increasing compliance levels for the standard. Overall, the study finds that a high percentage of AC within manufacturing firms only covers the SEC's bare minimum requirements. Moreover, the paper presents evidence that the SEC's enforcement/monitoring activities (activities concerning IAS 24 requirements) have positively contributed to increasing standard compliance levels. A limitation of the study is that it only addresses the mandatory reporting requirements for IFRS. However, to better analyze disclosure compliance behaviors of financial report preparers, the analysis of voluntary disclosures and motivators for providing these voluntary disclosures could be beneficial. Moreover, future studies could work towards generating an effectiveness score concerning AC characteristics. Following this, the effectiveness score could be cross-referenced with IFRS compliance levels.

\section{REFERENCES}

Abdullah, M., Evans, L., Fraser, I., and Tsalavoutas, I. (2015). IFRS Mandatory disclosures in Malaysia: The influence of family control and the value irrelevance of compliance levels. Accounting Forum, 39(4), 328-348.

Agyei-Mensah, B. (2019a). The effect of Audit Committee attributes on compliance with IAS-24 related party disclosure: an empirical study, International Journal of Law and Management, 18 (5), 779-808.

Agyei-Mensah, B. (2019b) The effect of audit committee effectiveness and audit quality on corporate voluntary disclosure quality. African Journal of Economic and Management Studies. 10 (1), 17-31.

Ahmed, A., Neel, M. and Wang, D. (2012). Does Mandatory Adoption of IFRS Improve Accounting Quality?. Contemporary Accounting Research. 1 (1), 24-48 
Agyei-Mensah, B. K. (2017). The relationship between corporate governance mechanisms and IFRS 7 compliance: evidence from an emerging market. Corporate Governance: The International Journal of Business in Society. 17 (3), 446-465.

Alkurdi, A., Hussainey, K., Tahat, Y., \& Aladwan, M. (2019). The impact of corporate governance on risk disclosure: Jordanian evidence. Academy of Accounting and Financial Studies Journal. Online https://www.abacademies.org/articles/the-impact-of-corporate-governanceon-risk-disclosure-jordanian-evidence-7886.html

Al-Akra, M., Eddie, I. A., and Ali, M. J. (2010). The influence of the introduction of accounting disclosure regulation on mandatory disclosure compliance: Evidence from Jordan. The British Accounting Review, 42(3), 170-186.

Al-Shiab, M. (2003). Financial Consequences of IAS Adoption: The Case of Jordan. University of Newcastle Upon- UK: Tyne.

Alanezi, F. S., and Albuloushi, S. S. (2011). Does the existence of voluntary ACs really affect IFRS-required disclosure? The Kuwaiti evidence. International Journal of Disclosure and Governance, 8(2), 148-173.

Al Sawalqa, F. (2014). Corporate governance mechanisms and voluntary disclosure compliance: The case of banks in Jordan. International Journal of Academic Research in Accounting. Finance and Management Sciences, 4(2), 369-384.

Baboukardos, D., and Rimmel, G. (2014). Goodwill under IFRS: Relevance and disclosures in an unfavorable environment. Accounting Forum. 38 (1), $1-17$.

Bananuka, J., Kadaali, A. W., Mukyala, V., Muramuzi, B., and Namusobya, Z. (2019). Audit Committee effectiveness, isomorphic forces, managerial attitude and adoption of international financial reporting standards. Journal of Accounting in Emerging Economies. 9(4), 502-526.

Barth, M. E., Landsman, W. R., \& Lang, M. H. (2008). International Accounting Standards and Accounting Quality. Journal of Accounting Research, 46(3), 467-498.

Beattie, A. McInnes,B. and Fearnley, S. (2004). A methodology for analyzing and evaluating narratives in annual reports: A Comprehensive Description Profile and Metrics for Disclosure Quality Attributes. Accounting Forum 28 (1), 205-236.

Bepari, M. K., and Mollik, A. T. (2015). Effect of audit quality and accounting and finance backgrounds of Audit Committee members on firms' compliance with IFRS for goodwill impairment testing. Journal of Applied Accounting Research. 16 (2), 196-220.

Muhasebe ve Vergi Uygulamaları Dergisi 
Bepari, M. K., Rahman, F. S., and Mollik, T. A. (2014). Firms' compliance with the disclosure requirements of IFRS for goodwill impairment testing: Effect of the global financial crisis and other firm characteristics. Journal of Accounting and Organizational Change, 10(1), 116- 149.

Botosan, A. (1997). Disclosure level and the cost of equity capital. The Accounting Review. 72 (3), 323-350.

Cairns, D. (1997). Developing Countries Always on the Agenda. Accountancy, 119(1244), 62-67.

Cafaggi, F., and Renda, A. (2012). Public and private regulation: mapping the labyrinth.

Online

https://papers.ssrn.com/sol3/papers.cfm?abstract_id=2156875

Cascino, S., and Gassen, J. (2015). What drives the comparability effect of mandatory IFRS adoption? Review of Accounting Studies, 20(1), 242-282.

Cooke, E. (1992). The impact of size, stock market listing and industry type on disclosure in the annual reports of japanese listed corporations, Accounting and Business Research. 22(87), 229 - 237.

Davies, J. C. (1983). The effects of federal regulation on chemical industry innovation. Law and Contemp. Probs., 46 (1), 41-58.

Daryanto A. (2018). SPSS Heterogeneity Macro. Online https://sites.google.com/site/ahmaddaryanto/scripts/Heterogeneity-test

Dawd, I. (2018). Aggregate financial disclosure practice: evidence from the emerging capital market of Kuwait. Journal of Applied Accounting Research. 21(1), 626-647.

Ernawati, D., and Aryani, Y. A. (2019). Controlling shareholders, Audit Committee characteristics, and related party transaction disclosure: Evidence from Indonesia. Jurnal Keuangan dan Perbankan, 23(1), 14-28.

El Mahdy, D. F., Hao, J., and Cong, Y. (2019). Audit Committee Financial Expertise and Information Asymmetry. Online https://papers.ssrn.com/sol3/papers.cfm?abstract_id=3423298

Ettredge, M., Johnstone, K., Stone, M., and Wang, Q. (2011). The effects of firm size, corporate governance quality, and bad news on disclosure compliance. Review of Accounting Studies, 16(4), 866-889.

Fekete, S., Matis, D., and Lukács, J. (2008). Factors influencing the extent of corporate compliance with IFRS-The Case of Hungarian listed companies. Online https://papers.ssrn.com/sol3/papers.cfm?abstract_id=1295722

Field, A.P. (2009). Discovering statistics using SPSS: and sex and drugs and rock 'n' roll (3rd edition). London: Sage. 
Goh, L., Joos, P., and Soonawalla, K. (2016). determinants and valuation implications of compulsory stock option disclosures in a weak regulatory setting - the case of France. Journal of International Financial Management and Accounting, 27(1), 26-64.

Gordon, E. and Henry , E. (2005). Related Party Transactions and Earnings Management.

Online. https://papers.ssrn.com/sol3/papers.cfm?abstract_id=612234

Hair, J., Black, W. Babin, B and Anderson R. (2014). Multivariate Data Analysis. Essex: Pearson.

Hartwig, F. (2015). Swedish and Dutch listed companies' compliance with IAS 36 paragraph 134. International Journal of Disclosure and Governance, 12(1), 78-105.

Haniffa, R., and Hudaib, M. (2006). Corporate governance structure and performance of Malaysian listed companies. Journal of Business Finance \& Accounting, 33(7-8), 1034-1062.

Hellman, N. (2008). Accounting Conservatism under IFRS. Accounting in Europe, 5(2), 71-100.

International Accounting Standards Board (2020). About. Online https://www.ifrs.org/

Jackson, E. and Roe, J. (2009). Public and Private enforcement of securities laws: resource-based evidence. Journal of Financial Economics (JFE). 93. (1), 15-35.

Kabara, A. S., Abdullah, D. F., and Othman, A. (2019). The effect of governance code compliance on Audit Committee diversity and corporate voluntary disclosure: evidence from dynamic panel approach. Polish Journal of Management Studies, 20 (1), 223-232.

Laux, V. and Stocken P. (2013). Accounting Standards, Regulatory Enforcement,and Investment Decisions. University of Texas 1 (1), 1-52.

Leuz, C. (2010). Different approaches to corporate reporting regulation: How jurisdictions differ and why. Accounting and Business Research, 40(3), 229-256.

Leuz, C., and Wysocki, P. D. (2008). Economic consequences of financial reporting and disclosure regulation: A review and suggestions for future research.

Online https://papers.ssrn.com/sol3/papers.cfm?abstract_id=1105398

Leuz, C., Triantis, A., and Wang, T. Y. (2008). Why do firms go dark? Causes and economic consequences of voluntary SEC deregistrations. Journal of Accounting and Economics, 45(2), 181-208. 
Lopes, P. T., and Rodrigues, L. L. (2007). Accounting for financial instruments: An analysis of the determinants of disclosure in the Portuguese stock exchange. The International Journal of Accounting, 42(1), 25-56.

Marston, C., and Philip S.. (1996) A review of empirical research into financial disclosure. European Accounting Association meetings, Bergen.

Mayorga, D. and Sidhu, B., (2012). Corporate disclosures of the major sources of estimation uncertainties. Australian Accounting Review. 22 (1), 25-39.

Mgammal, M. H., Bardai, B., and Ismail, K. N. I. K. (2018). Corporate governance and tax disclosure phenomenon in the Malaysian listed companies. Corporate Governance: The International Journal of Business in Society.18(5), 779-808.

Mnif, Y., and Znazen, O. (2020). Corporate governance and compliance with IFRS 7: The case of financial institutions listed in Canada. Managerial Auditing Journal. 35(3), 448-474.

Musleh Al-Sartawi, A., Alrawahi, F., \& Sanad, Z. (2016). Corporate governance and the level of compliance with international accounting standards (IAS-1): Evidence from Bahrain Bourse. Online https://papers.ssrn.com/sol3/papers.cfm?abstract_id=2898145

Nobes, C., (2006). The survival of international differences under IFRS: towards a research agenda. Accounting and Business Research, 36(3), 233245.

Omran, M. A., and Abdelrazik, M. (2013). The association between corporate governance and corporate disclosure: A critical review. Journal of public administration and governance, 3(3), 94-107.

Persaud, A. D. (2015). Why do we regulate finance?. Reinventing Financial Regulation (pp. 7-23). Berkeley, CA: Apress.

Public Disclosure Platform. (2020). Sektör. Online https://www.kap.org.tr/en/

Public Oversight Accounting and Auditing Standards Authority (2020). TFRS TMS Setlerl Online https://www.kgk.gov.tr/Home

Rechtschaffen, C. (2007). Shining the spotlight on European Union environmental compliance. Pace Envtl. L. Rev., 24, 161.

Santos, E. S., Ponte, V. M. R., and Mapurunga, P. V. R. (2014). Mandatory IFRS adoption in Brazil (2010): Index of compliance with disclosure requirements and some explanatory factors of firms reporting. Revista Contabilidade and Finanças, 25(65), 161-176. 
Stenka, R. I., Ormrod, P., \& Chan, A. (2008). Accounting for Business Combinations-The Consequences of IFRS Adoption for UK Listed Companies. https://papers.ssrn.com/sol3/papers.cfm?abstract_id=1276826

Schultz Jr, J. J., and Lopez, T. J. (2001). The impact of national influence on accounting estimates: Implications for international accounting standardsetters. The International Journal of Accounting, 36(3), 271-290.

Tahat, Y., Mardini, G. H., and Power, D. M. (2017). Factors affecting financial instruments disclosure in emerging economies: the case of Jordan. Afro-Asian Journal of Finance and Accounting, 7(3), 255-280.

Talpur, S., Lizam, M., and Zabri, S. M. (2018). Do Audit Committee structure increases influence the level of voluntary corporate governance disclosures?. Property Management. 36 (5), 544-561.

Tsalavoutas, I. (2011). Transition to IFRS and compliance with mandatory disclosure requirements: What is the signal?. Advances in Accounting, 27(2), 390-405.

Tsalavoutas, I. Evans, L. and Smith, M. 2010. Comparison of Two Methods For Measuring Compliance with IFRS Mandatory Disclosure Requirements. Journal of Applied Accounting Research. 11(3), 213-228.

Tsalavoutas, I., and Dionysiou, D. (2014). Value relevance of IFRS mandatory disclosure requirements. Journal of Applied Accounting Research, 15(1), 22-42.

Tsalavoutas, I., Tsoligkas, F., and Evans, L. (2020). Compliance with IFRS mandatory disclosure requirements: a structured literature review. Online https://papers.ssrn.com/sol3/papers.cfm?abstract_id=3513301

Taylor, G., Tower, G., Van Der Zahn, M., and Neilson, J. (2008). Corporate governance determinants on Australian resource companies' financial instrument disclosure practices. Asian Review of Accounting. 16 (1), 56-73.

International Accounting Standards 24 (IAS 24) (2019). IAS 24 Related Party Disclosures. Online https://www.kgk.gov.tr/Portalv2Uploads/files/DynamicContentFiles/T\%C3 $\%$ BCrkiye \%20Muhasebe $\% 20$ Standartlar\%C4\%B1/TMSTFRS2018Seti/TM S/TMS_24_2018.pdf

Wang, X. (2018). Compliance over time by Australian firms with IFRS disclosure requirements. Australian Accounting Review, 29(4), 679-691. 